\title{
Bank-Insurance Integration Level In Ukraine: Science-Methodological Approach
}

\author{
Kseniya Bagmet, Russian State Social University, Branch In Stavropol, Russia \\ Faten Ben Bouheni, ISC Paris Business School, France \\ Hassan Obeid, European Business School, France
}

\begin{abstract}
The methodological approach to the assessment of bank-insurance integration (BII) level in Ukraine based on the calculation of integration index using of binary characteristics and matrix analyses instruments is given in the following paper. The proposed approach considers the presence of part (full) integration of bank capital and insurance companies, and the connection between these financial intermediaries in spheres of life and risk insurance in terms of the absence of their mutual participation in capital (bancassurance). Our findings evidence a low value of BII level in Ukraine during 2002-2013 in conditions of the gradual integration processes' acceleration and the appearance of new innovative forms of bank-insurance cooperation.
\end{abstract}

Keywords: Bank; Insurance Company; Financial Group; Integration Level; Bancassurance

\section{INTRODUCTION}

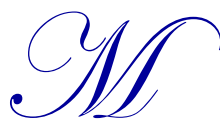

odern world business architecture is characterized by widening and deepening of integration interconnections among financial intermediaries. Bank-insurance integration became the most noticeable phenomenon of macroeconomic process, the level of which to some extent sets the conditions for development of financial sector of economics according to the phase of cycle at the present moment. From the one side, at the raise of business activity at the high level of bank-insurance integration financial intermediaries get quicker and flexible access to internal and external investment resources that in its turn promote faster development of the financial sector and economic growth of the country in general. From the other side, in the slump phase of business activity presence of close integration interconnections between banks and insurance companies becomes threatening.

As the diffusion of crises impulses from bank segment on insurance segment is distributing faster and destabilize functioning of the financial sector in general, regulation of the mentioned above processes and preventing the financial sector turbulence becomes possible in the conditions of having information about character and level of the integration. This position of the question explains the necessity of working out the methodological base of bank-insurance integration level with the aim to define the tools that can influence these processes on the example of Ukraine during 2002-2013.

Our findings show a low BII level in Ukraine in 2002-2013, which could be explain by myriad problems, such as legislative, conjectural, organizational (infrastructural), information and technological problems, and problems in the area of interaction with customers. Solving of the mentioned issues demands: 1) evolution of legislative base of financial groups activity regulation; 2) regulation of relations between insurance companies and insurance agents (banks) on the base of delivered open and pure accreditation insurance companies in banks; 3) implementation of set off mechanism of insurance companies' funds placed on bank's deposits during moratorium on their early withdrawal, and funds of bank-beneficiary according to the insurance contract as counterclaims; 4) implementation of interim financial reporting for insurance companies, with obligatory information disclosure connected with the insurance premiums volume, gathered according to the each type of insurance (life or non-life) through bank distribution channel; 5) gradual implementation of the Directives of the European Parliament and of the Council of Europe Basel II, Basel III, in particular, concerning the formation of countercyclical capital buffers 
by banks; 6) development of prudential and macro-prudential control of banks and insurance companies' activity. Implementation of such recommendations will let to enroll the possibilities of Ukrainian insurance companies and banks' consolidation from one side (it means the level of their safe integration for financial sector functioning), but from the other side will not allow the expansion of negative consequences in bank functioning on insurance companies activity, and also will help the effective regulation of financial groups activity and providing a stable functioning of the financial sector of economy in whole.

\section{POTENTIAL USERS OF INFORMATION ABOUT THE ESTIMATION OF THE BII LEVEL IN UKRAINE}

A thorough analysis of domestic and foreign researches (Cetorelli and Goldberg, 2011; Chen et al. 2014; Cummins and Weiss, 2010; Ghimire, 2013; Jeon et al. 2013; Kist, 2001; Schoenmaker, 2013) proves the absence of methodological approaches to bank-insurance integration level in the country. Anyway the results of such estimation are interesting for a range of subjects, the characteristics of which are presented at the Figure 1.

Figure 1. Ways of using and potential users of information about the estimation of BII level in Ukraine

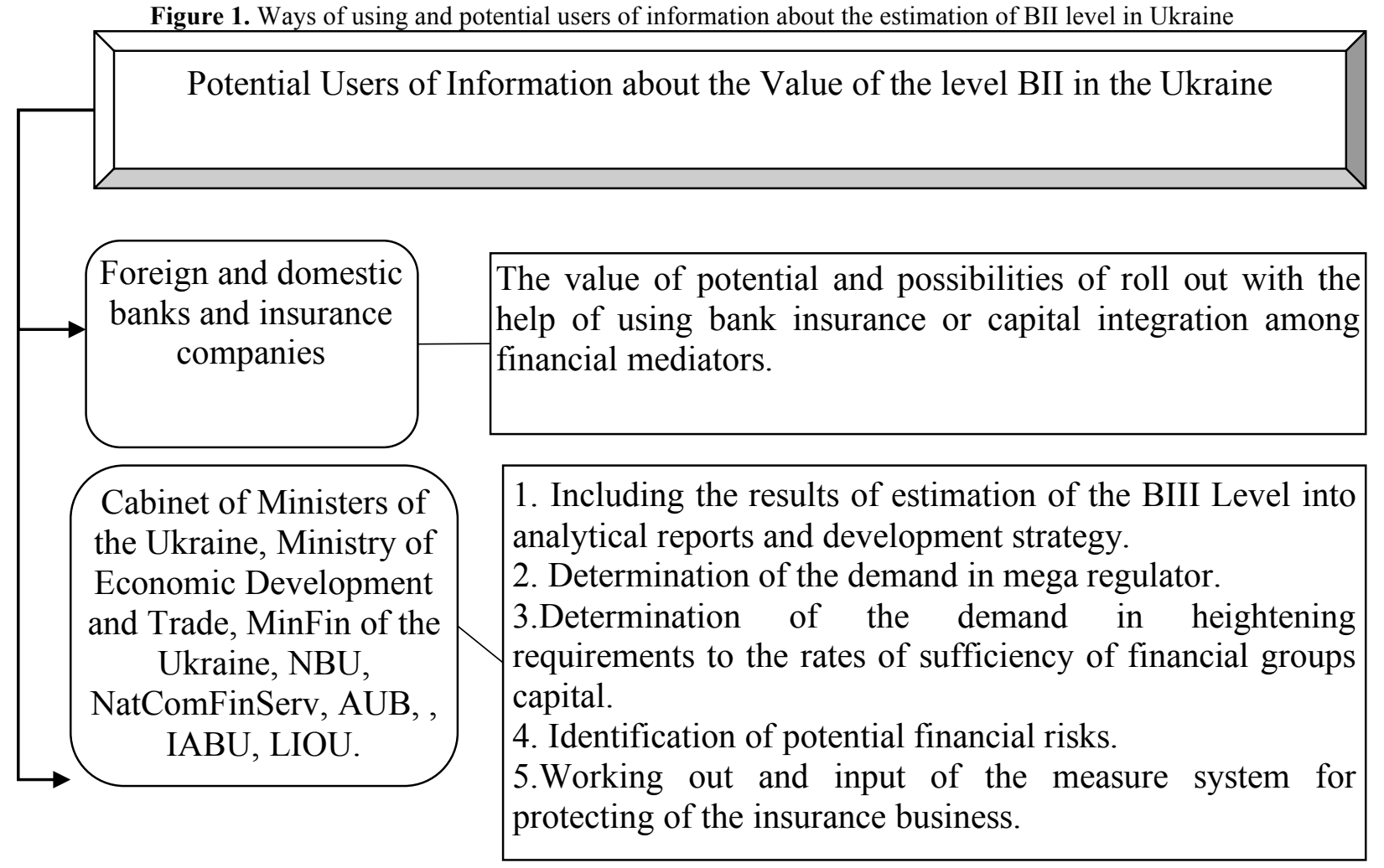

Despite the direct participants of integration processes (banks and insurance companies) the potential users of information about the estimation of BII level in Ukraine are state regulation and control authorities and selfregulating organizations. Thus, for example, the National Bank of Ukraine (NBU), National commission of state regulation in the sphere of financial service markets (NatComFinServ), Association of Ukraine's Banks (AUB), Independent Association of Banks of Ukraine (IABU), League of Insurance Organizations of Ukraine (LIOU) can use the obtained data for preparation of analytical reports about the modern condition and tendencies of development of bank and insurance business segments of economic sector, and also while the process of management decision making connected with: 


\section{a) Determination of the necessity in mega regulating creating in Ukraine:}

At the heightened or high levels of integration the creating of consolidative structure of supervision in Ukraine will be objectively necessary. But currently it is needful to think about the necessity of uniting supervising functions in different spheres of financial markets in the nearest perspective. The system of consolidative supervision over financial groups activity in present conditions of Ukraine economic development can be formed without establishing the unified authority of state regulation, at the expanse of increasing of interconnections and the level of coordination among different in their functions authorities of state supervision. Taking into account the low level of bank-insurance integration in the Ukraine, the most optimal form of consolidative supervision can be legislative proved multilateral agreement among NBU, NCFS and National Commission on the Capital Issues and Fond Market (NCCIFM). From the other side, taking into account the dynamics of the BII development and bankoriented financial system in the Ukraine, establishment of mega regulator on the base of the National Bank of Ukraine can become the objective demand in short-term perspective. It must be noted that while the research was in process the National Bank of Ukraine proved a new concept of bank system reforming in Ukraine till 2020, which supposes the forming of mega regulator on the base of central bank of the country. So the diversion of insurance companies for NBU supervision is supposed to implement till the middle of 2015, stocks market regulation - till the middle of 2016.

\section{b) Determination of the necessity to increase the requirements of capital adequacy of financial groups.}

The question of creating the unified and standardized system of regulation of the capital adequacy of financial groups is remaining topical, as the requirements to the minimum authorized capital amounts of banks and insurance companies $(120 \mathrm{mln}$ hrn. or $1(1,5) \mathrm{mln}$ euro) and the method of calculation of capital adequacy differ significantly. Moreover, methodological approach to definition of sufficient amount of financial group's capital requires further researches. It is obvious that with the aim of risks' protection the minimum amount of the total group's capital must exceed than the absolute sum of minimum amounts of authorized capitals of banks and insurance companies. This, first of all, is caused by the possibility of «multiplicative effect» occurrence among bank risks, arising mostly in assets, and among insurance companies which as a rule are related to liabilities.

c) Identification of potential systemic risks, which can be realized as a result of increased and high BII levels.

d) Working out and adoption of system of measures for insurance market protection from the negative consequences of financial crises caused by ineffective bank activity.

\section{DATA AND METHODS}

Author's approach to the formalization of BII level assumes the calculation of the integral index «LBII» - «Level of the banking and insurance integration» (Figure 2), where:

$x_{i}$ - quantitative value of $i$ - indicator $(i=1 \div 9)$;

$j$-indicator of integration level $(j=1 \div 4)$;

$\alpha$-weight coefficient of $i$-indicator $(i=1 \div 9)$;

$t_{i j}$ - binary characteristics of $i$-indicator correspondence to $j$-level of integration;

$c_{i j}$ - characteristics of the intensiveness of quantity meaning of $i$ - indicator influence on $j$ - level of integration;

$t_{m j}$ - binary characteristics of the intensiveness of quality value influence of the value of $i$ - indicator for the conforming level of BII $(m=1 \div 36)$;

$\ell$ - indicator of determination of the low, middle and high maximum borders of BII levels. 
Figure 2. Methodological approach to the estimation of bank-insurance integration level

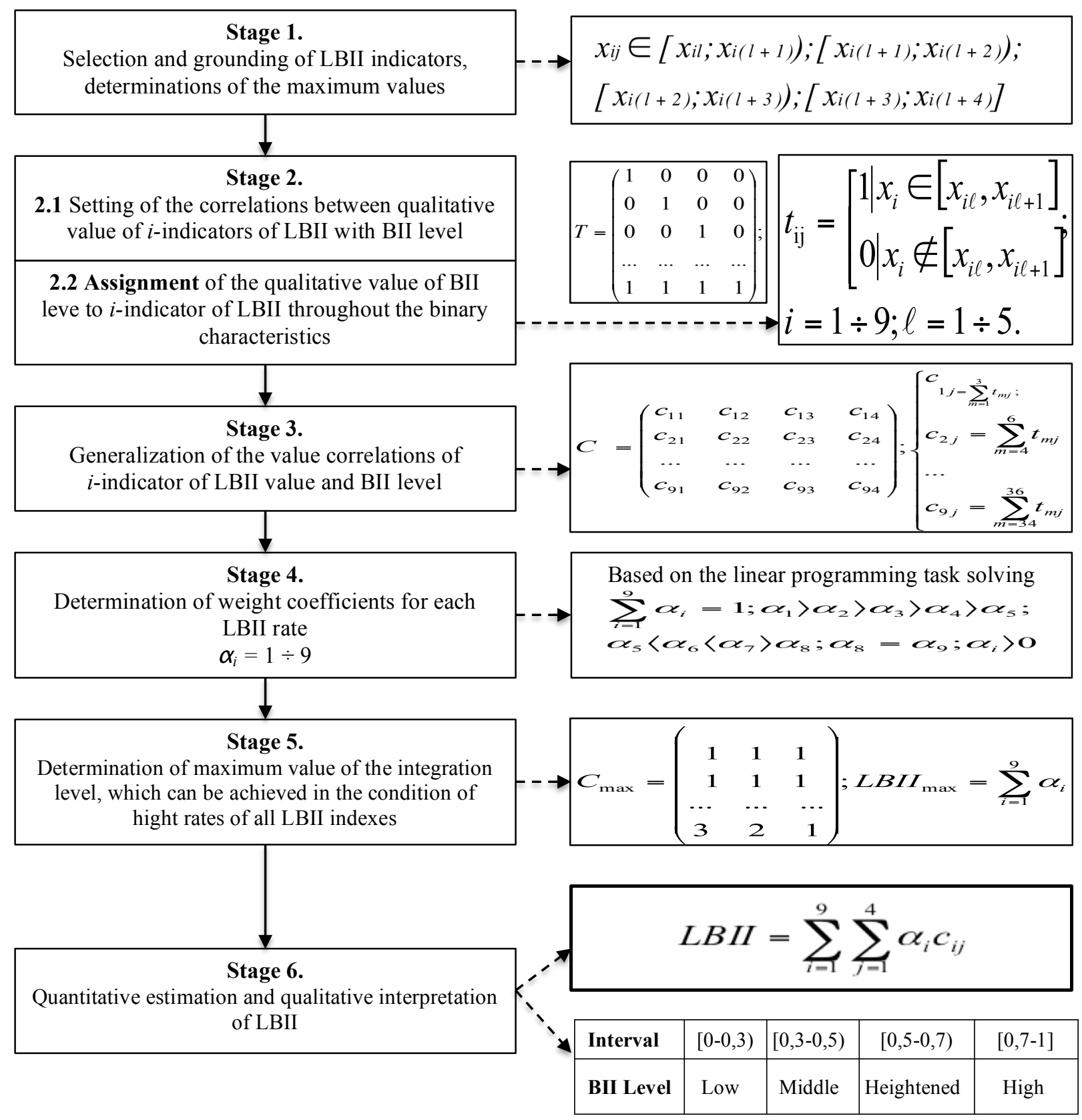

The first stage of formed approach supposes the selection and grounding of individual indexes of LBII esteem, and determination of their maximum values (Figure 3). 
Figure 3. The maximum values of BII rate estimation in Ukraine

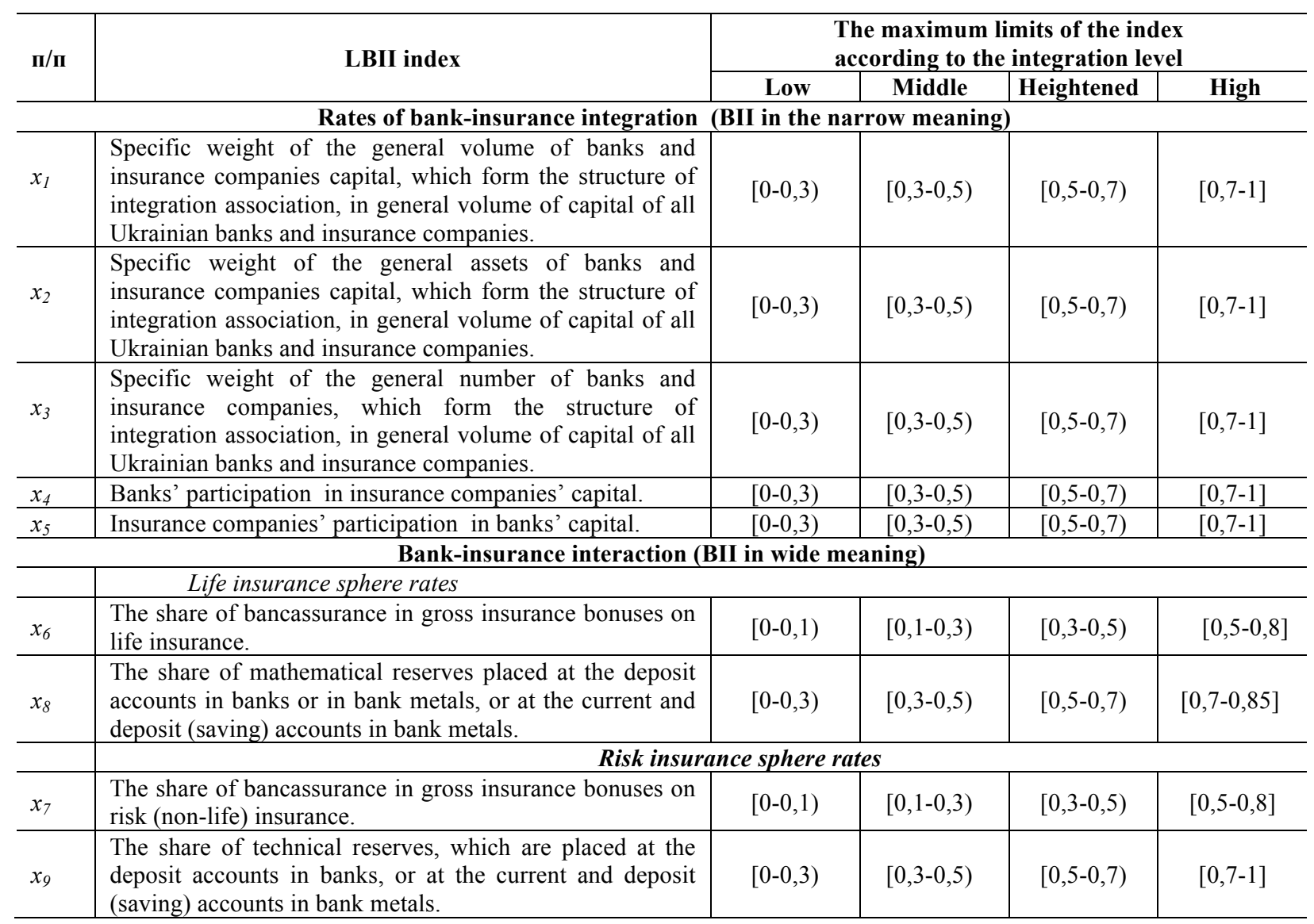

The given list of indicators is formed on the base of elaborated by the author classification of types and forms of bank-insurance interaction implementation (Figure 4). 
Figure 4. Types and Forms of Bank-Insurance Interaction

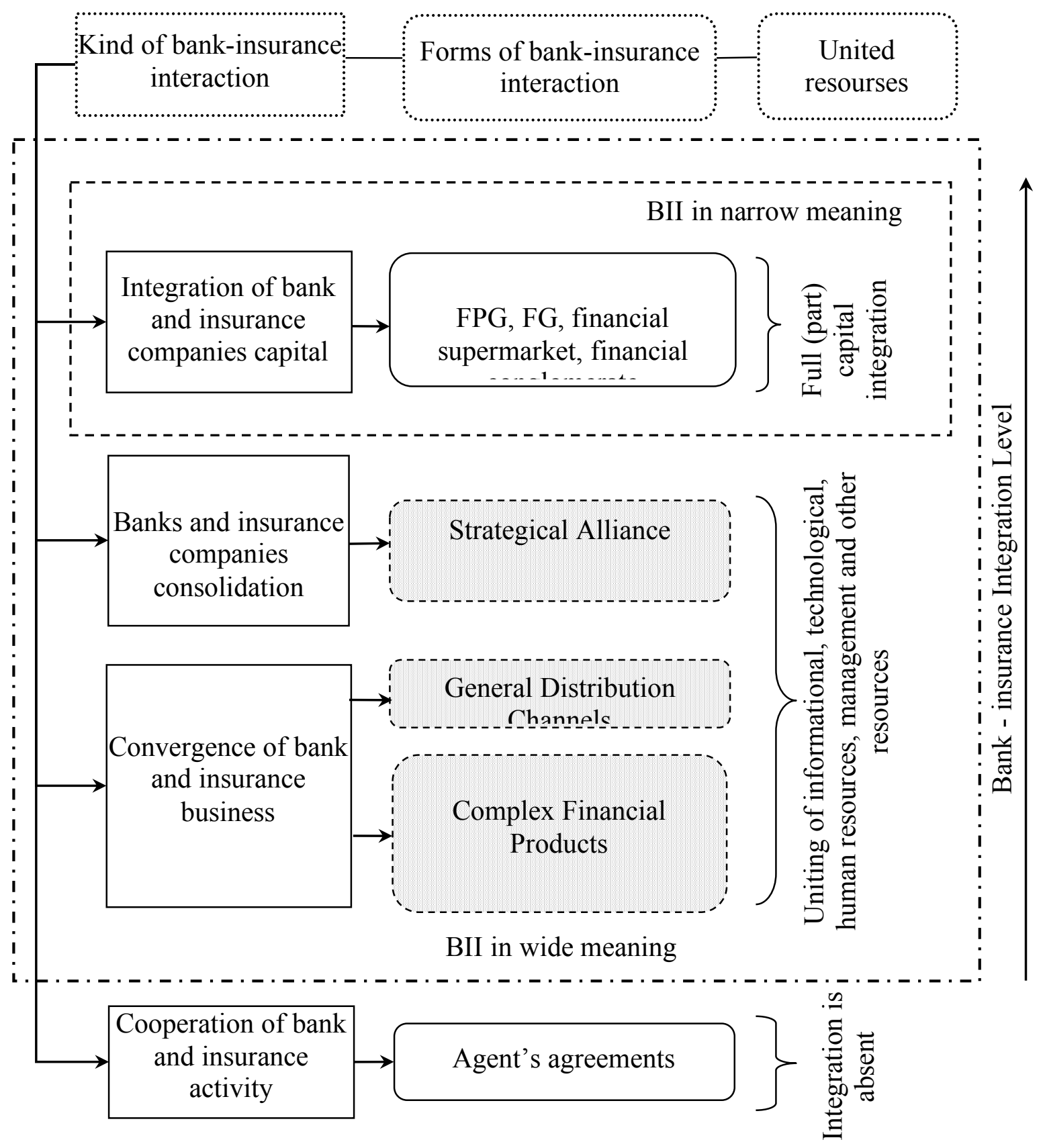

\section{Bank-insurance}

The first part of indexes (see Figure 3) characterizes the density of integration connections among banks and insurance companies, and takes into consideration the presence of the direct participation in capital - the BII in its narrow definition (see Fig. 4). The second group includes the indexes, characterizing the presence of interactions, unconnected with banks and insurance companies assets integration. In fact the discussion is about: 1) using by financial intermediaries such form of bank-insurance integration as bancassurance, which does not demand the direct capital uniting; 2) using by the insurance companies such ways of own insurance reserves replacement as deposit accounts in banks and bank metals. 
Accounting of each from nine indexes gives the possibility to estimate the level of bank-insurance integration in wide sense, particularly as the process of capital consolidation (participation in capital) of banks and insurance companies or the joint using of their informational, technological, human resources, managerial and other resources while implementing mutual functions, the result of which is the achievement of the given subjects the definite positive (negative) synergetic effect (micro level) and changing the character of financial sector development (macro level).

The question of determination of qualitative characteristic of bank-insurance integration level and their maximum limits is very important and practically essential. Segregation of four BII levels is proposed in this research. It has the following gradation: low, middle, heightened, high. In this case interval's distribution fits the existing in econometrics and statistics [Hastie et. al (2008)] approach, which concerns the definition of maximum limits for estimation of tightness of interrelation among factors' attributes and effective index: $[0-0,3)-$ the connection is poor (low BII level); [0,3 - 0,5) - noticeable connection (middle BII Level); $[0,5$ - 0,7) - close connection (heightened BII level); [0,7 - 1,0] - strong connection (high BII level). The exceptions are only the maximum limits of the second group indicators, such as $x_{6}, x_{7}, x_{8}$, which is explained in the following way.

Indicators of life insurance sphere. Taking into account the world experience of bank-insurance organizing, the maximum value of bancassurance share in gross insurance bonuses on life insurance during 1999-2009 was typical for Portugal and reached $« 0,88 »$ (Kozmenko and Bagmet, 2011). The level of bank-insurance market in this country is considered to be high according to practitioners and theorists views. On this bases we can assume that the maximum value of index $x_{6}$ can be equal to $« 0,90 »$. This value can be higher in theory, but it is necessary to consider the presence of other non-banking channels of insurance products distribution, such as: direct sales by the insurance companies' assistants (office method), agents, brokers.

The other index is the share of mathematical reserves placed at deposit accounts in banks, as bank metals, including at the current and saving (deposit) accounts in bank metals. The maximum value of the marginal limit of the index $x_{8}$ is chosen at the level $« 0,85 »$. It is connected with the existing legislative limitations concerning the possible volumes of insurance reserves placement on life insurance. So, according to the Directive of the National Commission that executes the state regulation in sphere of financial services of Ukraine «The Rules of Placement of Insurance Reserves on Life Insurance» № 2875 dating from 11.26.2004 ${ }^{1}$ insurance companies may place at the bank deposits not more than $70 \%$ insurance reserves, in bank metals not more than $15 \%$.

Indexes in risk insurance sphere. The maximum value of bancassurance share in gross insurance bonuses on risk insurance is offered to be at the level «0,80», which considers the real maximum value of such index in European countries (Italy, Spain) (Kozmenko and Bagmet, 2011). Thus, theoretically the $x_{7}$ index can take values in the range $\ll 0,90-1,00 »$, though it has never been observed in any country, because of higher level of distribution of life insurance products. Because of absence of legislative limits in Ukraine according to the volumes of insurance reserves placement in other kinds of insurance, than life insurance ${ }^{2}$, the marginal maximum value of technical reserves share, placed in deposit bank accounts and in bank metals $\left(x_{9}\right)$ is offered to set at the level «1,00».

At the second stage the quantitative estimation of each from nine indexes is conducted $\left(\begin{array}{lll}x_{I} & \ldots & x_{9}\end{array}\right)$ and identification of interconnection of the qualitative value of $i$-indicator (low, middle, heightened, high) with the corresponding BII level (low, middle, heightened, high) the results of which are presented in the Figure 5.

\footnotetext{
${ }^{1}$ About the Rules of Placement of Insurance Reserves on Life Insurance [Eelectronic resource] / the Direction of the National Commission for regulating of financial services dated from 26.11.2004, №2875: http://zakon1.rada.gov.ua/laws/show/z0948-09.

${ }_{2}^{2}$ About the Rules of Placement of Insurance Reserves on Non-Life Insurance [Eelectronic resource] / the Direction of the National Commission for regulating of financial services dated from 20.05.2010, №422: http://zakon1.rada.gov.ua/laws/show/z0373-10.
} 
Figure 5. Identification of interconnection among quality estimations of individual indicators and BII level

\begin{tabular}{|c|c|c|c|c|c|}
\hline \multirow{2}{*}{\multicolumn{2}{|c|}{ Qualitative estimation of indicator }} & \multicolumn{4}{|c|}{ Integration Level } \\
\hline & & Low & Middle & Heightened & High \\
\hline \multirow{4}{*}{$x_{1}$} & Low & 1 & 0 & 0 & 0 \\
\hline & Middle & 0 & 1 & 0 & 0 \\
\hline & Heightened & 0 & 0 & 1 & 0 \\
\hline & High & 0 & 0 & 0 & 1 \\
\hline \multirow{4}{*}{$x_{2}$} & Low & 1 & 0 & 0 & 0 \\
\hline & Middle & 0 & 1 & 0 & 0 \\
\hline & Heightened & 0 & 0 & 1 & 0 \\
\hline & High & 0 & 0 & 0 & 1 \\
\hline \multirow{4}{*}{$x_{3}$} & Low & 1 & 1 & 0 & 0 \\
\hline & Middle & 0 & 1 & 1 & 0 \\
\hline & Heightened & 0 & 0 & 1 & 1 \\
\hline & High & 0 & 0 & 0 & 1 \\
\hline \multirow{4}{*}{$x_{4}$} & Low & 1 & 0 & 0 & 0 \\
\hline & Middle & 0 & 1 & 0 & 0 \\
\hline & Heightened & 0 & 0 & 1 & 0 \\
\hline & High & 0 & 0 & 0 & 1 \\
\hline \multirow{4}{*}{$x_{5}$} & Low & 1 & 1 & 1 & 1 \\
\hline & Middle & 0 & 1 & 1 & 0 \\
\hline & Heightened & 0 & 0 & 1 & 1 \\
\hline & High & 0 & 0 & 0 & 1 \\
\hline \multirow{4}{*}{$x_{6}$} & Low & 1 & 0 & 0 & 0 \\
\hline & Middle & 0 & 1 & 1 & 1 \\
\hline & Heightened & 0 & 0 & 1 & 1 \\
\hline & High & 0 & 0 & 1 & 1 \\
\hline \multirow{4}{*}{$x_{7}$} & Low & 1 & 0 & 0 & 0 \\
\hline & Middle & 0 & 1 & 1 & 0 \\
\hline & Heightened & 0 & 0 & 1 & 1 \\
\hline & High & 0 & 0 & 1 & 1 \\
\hline \multirow{4}{*}{$x_{8}$} & Low & 1 & 0 & 0 & 0 \\
\hline & Middle & 1 & 1 & 0 & 0 \\
\hline & Heightened & 0 & 0 & 1 & 1 \\
\hline & High & 0 & 0 & 1 & 1 \\
\hline \multirow{4}{*}{$x_{9}$} & Low & 1 & 0 & 0 & 0 \\
\hline & Middle & 1 & 1 & 0 & 0 \\
\hline & Heightened & 0 & 1 & 1 & 1 \\
\hline & High & 0 & 1 & 1 & 1 \\
\hline
\end{tabular}

The aggregate values in table 2 can be presented as the matrix $T$, each element of which (depending from which interval has the $i$-indicator value) presents binary characteristics $\left(t_{i j}\right) \ll 1 »$ or «0» (formula $(1),(2)$ ).

$$
\begin{aligned}
& T_{36 \times 4}=\left(\begin{array}{cccc}
1 & 0 & 0 & 0 \\
0 & 1 & 0 & 0 \\
0 & 0 & 1 & 0 \\
\cdots & \cdots & \cdots & \cdots \\
1 & 1 & 1 & 1
\end{array}\right) \\
& t_{\mathrm{ij}}=\left[\begin{array}{l}
1 \mid x_{i} \in\left[x_{i \ell}, x_{i \ell+1}\right] \\
\mathrm{O} \mid x_{i} \notin\left[x_{i \ell}, x_{i \ell+1}\right]
\end{array}\right]=1 \div 9 ; \ell=1 \div 5 .
\end{aligned}
$$

The first index $x_{1}$ characterizes the specific weight of the total volume of capital of banks and insurance companies that compose the integrational associations, in total volume of all Ukrainian banks and insurance 
companies. This index is the most important for the estimation, because it allows to demonstrate the real BII level according to the definition given in the research in narrow meaning. That is why, if the value of this index is in the limits of interval «low», the level BII in financial sector of the country cannot be middle, heightened or high. It is shown in the table 2, that if $x_{I}$ would be characterized as «low» BII level would be low too and get a binary characteristic «1». Conformably, if the meaning of the given indicator is high, BII level in the country can be characterized as «high», or «heightened». But this does not prove the absence of the necessity in considering of other eight indexes $\left(x_{2}-x_{9}\right)$, because each of them has the supplementing character to the general value and helps to estimate BII level more accurate in wide sense.

The second in priority is the indicator of specific weight of the total volume of assets of bank and insurance companies that comprise the integration association in total volume of assets of all banks and insurance companies of the Ukraine. The necessity of its including into the system of LBII estimation indicators is conditioned by the following. Firstly, the volume of banks and insurance companies' assets exceeds the their capital volumes, so the calculation of $x_{2}$ index permits more accurate determination of the actual level of integration interaction among financial intermediaries. Secondly, the taken index helps to examine bank-insurance integration from the point of view of depositing of own resources by banks and insurance companies.

The necessity of including into the system of BII level estimation and the $x_{3}$ indicator (specific weight of banks and insurance companies quantity that comprise integrational financial groups in total quantity of all banks and insurance companies) is conditioned by:

(1) The participation of systemic banks and top-20 insurance companies in integration processes can cause high values of $x_{1}$ and $x_{2}$ indicators, considering high level of asset and capital concentration of such financial intermediaries, that finally can lead to the heightening of integral meaning of BII level index;

Theoretically the great amount of banks of the third (small) and the fourth (the smallest) groups according to the classification of the National Bank of Ukraine can take part in integration processes, and also captive insurance companies, which may have such level of effectiveness that may not influence on BII level, taking into account low values of the first two indicators in such case.

The identification of interrelation of each qualitative estimation (low, middle, heightened, high meaning) of $x_{6}$ index (share in bancassurance in gross insurance bonuses of life insurance) and $x_{7}$ index (share in bancassurance in gross insurance premiums of risk insurance) with the corresponding BII level (low, middle, heightened, high) needs more detailed explanation. Thus, for example, if the values of these indexes are low, the level of bankinsurance integration cannot be high or heightened. Thus, at the availability of great amount of financial groups the share of bancassurance in gross insurance premiums on risk insurance (more seldom in life insurance) will be characterized by heightened or high values. From the other side in case of high or heightened estimations of the mentioned above indexes the level of bank-insurance integration cannot be low theoretically. As a rule, if the country's share in bancassurance is more than $50 \%$ in average around the financial sector, it proves the presence of big financial groups, which provide complex bank-insurance products.

The third stage supposes the generalization of interconnection estimation of the value of $i$-indicator with BII level. Matrix $C$ is formed with this aim, every value of which $\left(c_{i j}\right)$ is equal to the sum of binary characteristics of four quantitative estimations of corresponding index (3). 


$$
C=\left(\begin{array}{llll}
c_{11} & c_{12} & c_{13} & c_{14} \\
c_{21} & c_{22} & c_{23} & c_{24} \\
c_{31} & c_{32} & c_{33} & c_{34} \\
c_{41} & c_{42} & c_{43} & c_{44} \\
c_{51} & c_{52} & c_{53} & c_{54} \\
c_{61} & c_{62} & c_{63} & c_{64} \\
c_{71} & c_{72} & c_{73} & c_{74} \\
c_{81} & c_{82} & c_{83} & c_{84} \\
c_{91} & c_{92} & c_{93} & c_{94}
\end{array}\right), \text { де }\left\{\begin{array}{c}
c_{1 j}=\sum_{m=1}^{4} t_{m j} \\
c_{2 j}=\sum_{m=5}^{8} t_{m j} \\
c_{3 j}=\sum_{m=9}^{12} t_{m j} \\
\cdots \\
c_{9 j}=\sum_{m=32}^{36} t_{m j}
\end{array}\right.
$$

The fourth stage. Considering different character and force of impact of each from nine indexes on the BII level, it is reasonable to determine weight coefficients, $\left(\alpha_{i}, i=1 \div 9\right)$. On the base of linear programming there was made the calculation of nine weight coefficients at the base of enumeration of present system of limitation (4).

$$
\begin{aligned}
& \sum_{i=1}^{9} \alpha_{i}=1 \\
& \left.\left.\left.\left.\alpha_{1}\right\rangle \alpha_{2}\right\rangle \alpha_{3}\right\rangle \alpha_{4}\right\rangle \alpha_{5} ; \\
& \alpha_{5}\left\langle\alpha_{6}\left\langle\alpha_{7}\right\rangle \alpha_{8}\right. \\
& \alpha_{8}=\alpha_{9} \\
& \left.\alpha_{i}\right\rangle 0
\end{aligned}
$$

The real values of weight coefficients are presented in the Figure 6.

Figure 6. Weight coefficient of BII level value index

\begin{tabular}{cccccccccc}
\hline Weight coefficient & $\boldsymbol{\alpha}_{1}$ & $\boldsymbol{\alpha}_{2}$ & $\boldsymbol{\alpha}_{3}$ & $\boldsymbol{\alpha}_{4}$ & $\boldsymbol{\alpha}_{5}$ & $\boldsymbol{\alpha}_{\boldsymbol{6}}$ & $\boldsymbol{\alpha}_{7}$ & $\boldsymbol{\alpha}_{\boldsymbol{8}}$ & $\boldsymbol{\alpha}_{\boldsymbol{9}}$ \\
\hline Meaning & 0,21 & 0,17 & 0,15 & 0,11 & 0,08 & 0,08 & 0,1 & 0,05 & 0,05 \\
\hline
\end{tabular}

The fifth stage supposes the determination of the maximum values which can be achieved in the conditions of high rates of all indexes $\left(x_{1}-x_{9}\right)$ LBII (5).

$$
C_{\max }=\left(\begin{array}{ccc}
1 & 1 & 1 \\
1 & 1 & 1 \\
\cdots & \ldots & \ldots \\
3 & 2 & 1
\end{array}\right) ; L B I I_{\max }=\sum_{i=1}^{9} \alpha_{i}
$$
2).

At the sixth stage the quantitative estimation and quantitive interpretation of the actual LBII are made (Figure

\section{RESULTS}

Let's make the estimation of the bank-insurance integration level in Ukraine on the base of proposed methodological approach. The specific of examining integration process in Ukraine is absence of statistical information and consolidating accountability of bank activities and insurance companies. This complicates the analyses of modern condition of bank-insurance integration and is one of the sharpest problems. Statistical base of research during 2002-2013 is formed in the Figure 7 on the base of sources ${ }^{3 ; 4 ; 5 ; 6}$ and authors' calculation. The

\footnotetext{
${ }^{3}$ Data of financial documentation of Banks in the Ukraine. Official site of the National Bank of Ukraine: http://www.bank.gov.ua/control/uk/ publish/category?cat_id $=74208(01.08 .2014)$

${ }_{4}^{4}$ Annual statement National Commercial Financial Service [Electronic resource ] http://www.dfp.gov.ua/734.html
} 
objects of the research are twenty-five banks and twenty-six insurance companies - members of financial groups and active participants of bancassurance in Ukraine during the studying period (see Figure 8). The fragment of calculating of the integral index of the bank-insurance integration level in 2008, when it was characterized as the highest. Summarized value of interrelation of qualitative estimation of $i$-indicator LBII with the BII level in 2008 is presented as a matrix $« c »(6)$.

$$
C=\left(\begin{array}{llll}
0 & 1 & 0 & 0 \\
0 & 0 & 1 & 0 \\
1 & 0 & 0 & 0 \\
0 & 0 & 0 & 1 \\
1 & 0 & 0 & 0 \\
0 & 1 & 1 & 1 \\
0 & 1 & 1 & 1 \\
0 & 1 & 1 & 1 \\
0 & 1 & 1 & 1
\end{array}\right)
$$

Substituting the elements of this matrix into the formula of LBII calculationaccording to the Figure 2, we'll get:

$$
\begin{aligned}
& \mathrm{LBII}=\alpha_{1} \times 0+\alpha_{2} \times 0+\alpha_{3} \times 0+\alpha_{4} \times 1+\alpha_{5} \times 0+\alpha_{6} \times 1+\alpha_{7} \times 1+\alpha_{8} \times 1+\alpha_{9} \times 1=0,11+0,08+0,08++0,1+0,05 \\
& +0,05=0,47 .
\end{aligned}
$$

The results of estimation evidence the low level of bank-insurance integration in the Ukraine, the values of which during 2002-2013 varied from 0,19 to 0,47 . The quantitative estimation and qualitative interpretation of the

\begin{tabular}{|c|c|c|c|c|c|c|c|c|c|c|c|c|}
\hline Year & 2002 & 2003 & 2004 & 2005 & 2006 & 2007 & 2008 & 2009 & 2010 & 2011 & 2012 & 2013 \\
\hline Value & 0,19 & 0,19 & 0,24 & 0,24 & 0,24 & 0.29 & 0,47 & 0,19 & 0,11 & 0,08 & 0,11 & 0,19 \\
\hline $\begin{array}{l}\text { Quantitative } \\
\text { estimation }\end{array}$ & & & Low & Level & & & $\begin{array}{l}\text { Middle BII } \\
\text { Level }\end{array}$ & \multicolumn{5}{|c|}{ Low BII Level } \\
\hline
\end{tabular}
estimation of bank-insurance integration level in Ukraine are presented in the Figure 8.

Figure 7. Dynamics of values of bank-insurance integration in Ukraine during 2002-2013

The results of calculation show that in 2008 bank-insurance integration level was characterized as high during the analyzed period. Thus, active credit portfolio growth was accompanied by the widening of insurance companies activity in the sphere of financial risks insurance, mortgage objects and life insurance of banks' borrowers till June 2008 (crises started in October-November 2008). Besides, on peak of economics in the Ukraine, financial intermediaries used bank-insurance very actively aiming to increase profit of their own business.

From the one side, it is possible to assume that such level is not threatening for financial sector of the Ukraine. But the 2008 crisis consequences proved the existence of the essential dependence between the effectiveness of banks and insurance companies' activity. It means that even in the conditions of low BII level at the phases of decay and crisis in economics the interaction of financial intermediaries in the form of bancassurance may be risky for insurance companies in the Ukraine.

\footnotetext{
5 Statistics of Ukrainian Banks Association [Electronic recourse]: http://aub.org.ua/index.php?option=com_lcontent\&task=view\&id= $87 \&$ menu $=104 \&$ Itemid $=96$

${ }^{6}$ Statistics of Insurance Market of Ukraine [Electronic recourse] /: http://forinsurer.com/stat/
} 
Figure 8. Statistical base of the estimation of the bank-insurance integration level in Ukraine during $2002-2013$

\begin{tabular}{|c|c|c|c|c|c|c|c|c|c|c|c|c|}
\hline \multirow{2}{*}{ Index } & \multicolumn{12}{|c|}{$\begin{array}{ll} & \text { Year }\end{array}$} \\
\hline & 2002 & 2003 & 2004 & 2005 & 2006 & 2007 & 2008 & 2009 & 2010 & 2011 & 2012 & 2013 \\
\hline Quantity of banks & 157 & 157 & 160 & 163 & 169 & 173 & 182 & 179 & 175 & 175 & 175 & 179 \\
\hline $\begin{array}{l}\text { Quantity of banks - BII } \\
\text { participants }\end{array}$ & 23 & 23 & 23 & 23 & 25 & 22 & 22 & 22 & 21 & 20 & 20 & 21 \\
\hline $\begin{array}{l}\text { Quantity of insurance } \\
\text { companies }\end{array}$ & 338 & 357 & 387 & 398 & 407 & 446 & 469 & 469 & 456 & 445 & 414 & 407 \\
\hline $\begin{array}{l}\text { Quantity of insurance } \\
\text { companies - BII participants }\end{array}$ & 12 & 14 & 15 & 19 & 22 & 22 & 22 & 19 & 18 & 18 & 19 & 19 \\
\hline$\left(x_{1}\right)$ & 0,3072 & 0,2842 & 0,2964 & 0,3196 & 0,3623 & 0,3615 & 0,3844 & 0,3169 & 0,2956 & 0,3280 & 0,3304 & 0,3345 \\
\hline$\left(x_{2}\right)$ & 0,4997 & 0,5097 & 0,4994 & 0,5229 & 0,5399 & 0,5282 & 0,5626 & 0,5066 & 0,5059 & 0,4974 & 0,5012 & 0,5098 \\
\hline$\left(x_{3}\right)$ & 0,0707 & 0,0720 & 0,0695 & 0,0749 & 0,0816 & 0,0711 & 0,0676 & 0,0633 & 0,0618 & 0,0613 & 0,0662 & 0,0683 \\
\hline$\left(x_{4}\right)$ & 0,7000 & 0,7000 & 0,7000 & 0,7000 & 0,7000 & 0,8000 & 1,0000 & 1,0000 & 1,0000 & 1,0000 & 1,0000 & 1,0000 \\
\hline$\left(x_{5}\right)$ & 0,0000 & 0,0000 & 0,0000 & 0,0000 & 0,0000 & 0,0000 & 0,0000 & 0,0000 & 0,0000 & 0,0000 & 0,0000 & 0,0000 \\
\hline$\left(x_{6}\right)$ & 0,0560 & 0,0562 & 0,0600 & 0,0640 & 0,0723 & 0,0834 & 0,1150 & 0,0570 & 0,0594 & 0,0620 & 0,06572 & 0,0756 \\
\hline$\left(x_{7}\right)$ & 0,1200 & 0,1600 & 0,1840 & 0,2350 & 0,2540 & 0,3100 & 0,3320 & 0,1745 & 0,1934 & 0,2635 & 0,2772 & 0,2803 \\
\hline$\left(x_{8}\right)$ & 0,3551 & 0,3670 & 0,4437 & 0,4698 & 0,5075 & 0,5176 & 0,5248 & 0,3739 & 0,3290 & 0,3356 & 0,3557 & 0,3635 \\
\hline$\left(x_{9}\right)$ & 0,2414 & 0,2027 & 0,188 & 0,4794 & 0,4618 & 0,4878 & 0,510 & 0,3565 & 0,3689 & 0,3437 & 0,3576 & 0,3647 \\
\hline
\end{tabular}


Figure 9. Bank and insurance companies - participants of BII in Ukraine during 2002-2013.

\begin{tabular}{|c|c|c|c|}
\hline $\begin{array}{c}\text { № } \\
\text { II/II }\end{array}$ & Banks & № & Insurance companies \\
\hline 1 & OJSC «Dongobank» & 1 & LTD «Veksel» \\
\hline 2 & OJSC «PUMB» & 2 & PSS IC «Alfa-Insuarance» \\
\hline 3 & OJSC «CreditPromBank» & 3 & PSS IC «Brokbusiness» \\
\hline 4 & OJSC «Credit-Dnipro» & 4 & 3AO CK «VAB Insurance» \\
\hline 5 & OJSC «Ukrsotsbank К» & 5 & PSS IC «Delta Life» \\
\hline 6 & OJSC «PrivatBank» & 6 & PSS IC «Renaissance», \\
\hline 7 & OJSC «Prominvestbank» & 7 & PSS IC «Arcade-Garant» \\
\hline 8 & OJSC «Riffizen Bank Aval» & 8 & $3 \mathrm{AO}$ «VAB Life» \\
\hline 9 & OJSC «Svedbank» & 9 & PSS IC «Renaissance Life» \\
\hline 10 & OJSC «TAS-investbank» & 10 & LTD «УASK ASKA» \\
\hline 11 & OJSC «Big-energy» & 11 & NASK «Oranta» \\
\hline 12 & OJSC «Pervy Investisionny Bank» & 12 & PSS IC «Etalon» \\
\hline 13 & LTD «Ukraine creditny bank» & 13 & $\mathrm{LTD} \ll \mathrm{TAS} »$ \\
\hline 14 & OJSC «Hreschatic» & 14 & $\mathrm{SS} \ll \mathrm{TAS} »$ \\
\hline 15 & OJSC «Ukrsibbank» & 15 & IC «Sky-Vest» \\
\hline 16 & OJSC «Nadra» & 16 & PSS IC «AHA Insurance» \\
\hline 17 & OJSC «Basis» & 17 & PSS IC «AHA Ukraine» \\
\hline 18 & OJSC «VTB Bank» & 18 & PSS IC «Kardif» \\
\hline 19 & OJSC «VAB bank» & 19 & LTD IC «Kardif Life» \\
\hline 20 & OJSC «Brokbusiness bank» & 20 & IC «General Garant» \\
\hline 21 & OJSC «Bank RenaissanceCapital» & 21 & LTD IC «General Garant Insurance of Life» \\
\hline 22 & OJSC «OTP Bank» & 22 & PSS IC «Unica life» \\
\hline 23 & OJSC «Alfa-Bank» & 23 & PSS IC «SEB Life Ukraine» \\
\hline 24 & OJSC «Delta Bank» & 24 & IC «TAS-capital» \\
\hline \multirow[t]{2}{*}{25} & OJSC «Arkada» & 25 & LTD «American company of life AIG Life» \\
\hline & & 26 & PSS IC «Alico Ukraine» \\
\hline
\end{tabular}

\section{CONCLUSION}

We apply the methodological approach to examine the level of bank-insurance integration in Ukraine during the period 2002-2013 using the calculation of integral index. We note that banks and insurance companies are the greatest and strongest financial intermediaries in the Ukraine. Our findings show a low BII level in Ukraine in 2002-2013, which could be explained by:

a. legislative problems: mainly weakness of effective regulating and supervision, law supporting of the activity of banks and insurance companies in the structure of integration financial groups;

b. conjectural problems: high level of dependence of insurance companies from banks; discrepancy of volumes of insurance dealership to banks; financial insolvency of insurance to take for insurance banks risks, characterizing by great loss;

c. problems of comparability of informational and technological sphere of banks and insurance companies, related to low automation level of business processes of insurance companies in comparison with banks; technical SOFT of banks does not include insurance products sale;

d. problems in sphere of interactions with clients: the accreditation of insurance companies in banks is not clear enough.

Solving of the mentioned above problems demands: 1) evolution of legislative base of financial groups activity regulation; 2) regulation of connections between insurance companies and insurance agents (banks) on the base of delivered open and pure accreditation insurance companies in banks; 3) implementation of mechanism of netting insurance companies money resources, which are placed on bank's deposits during moratorium for their anticipatory taking of, and assets of bank-beneficiary according to the insurance contract as homogenious opposite demands; 4) introduction of intermediate financial accountability for insurance companies, with obligatory 
information demonstration connected with the volume of insurance premiums, gathered according to the each type of insurance (life or non-life) through bank distribution channel; 5) step by step introduction of European parliament and Soviet of Europe directions Basel II, Basel III, in particular, counter cycling buffer of capital; 6) development of prudential and macro-prudential control of banks and insurance companies' activity. Realization of such events will let to enroll the possibilities of the Ukrainian insurance companies and banks' consolidation from one side (it means the level of their safe integration for financial sector functioning) but not to let the expansion of negative consequences from the other side in bank functioning connected with insurance companies activity, and also will help to the effective regulation of financial groups activity and providing a stable functioning of the financial sector in the economic in whole.

\section{AUTHOR INFORMATION}

Kseniya Bagmet. Areas of research: banking, insurance, integration process. She worked as Assistant to the Rector at Ukrainian academy of banking of the National bank of Ukraine.

Faten Ben Bouheni is Professor of Finance at ISC Paris Business School and Researcher at LITEM research laboratory in France. Her research focuses on financial institutions, with special emphasis on regulatory and supervisory issues.

Hassan Obeid is a head of Finance \& Accounting department at European Business School - Paris, his areas of research include company performance, bank efficiency, ICT and privatization. He is a member of the editorial board for academic journals. He has worked for AACSB accredited universities such as United Arab Emirates University and IESEG.

\section{REFERENCES}

Bagmet, K.V. (2014). Integration Interaction of Banks and Insurance Companies in the Ukraine: Problems and Their Solving. Problems of Modern Economics, 2, 322-326.

Balassa, B. (1982). The theory of economic integration. Greenwood Press, 304 p.

Bancassurance - new options for the development of Serbian financial sector (2011). Economics and Organization. 1, 15-29.

Basel Committee on Banking Supervision. Basel III: A global regulatory framework for more resilient banks and banking system. [Electronic resource] / Bank for International Settlements. - 2010 - Mode of Access : http://www.bis.org/publ/bcbs189.pdf - Title from the screen.

Basel III: What the draft proposals might mean for European banking April 2010 Philipp Härle Matthias Heuser Sonja Pfetsch Thomas Poppensieker [Electronic resource] / McKinsey\&Company. - 2010. - Mode of Access : http://ec.europa.eu/internal_market/bank/docs/gebi/mckinsey_en.pdf - Title from the screen.

Benoist G. (2002). Bancassurance: The New Challenges. The Geneva Papers on Risk and Insurance. 27 (3), 295 303.

Berger, A., Demsetz, R., Strahan, P. (1999). The consolidation of financial services industry: causes, consequences, and implications for the future. Journal of Banking \& Finance, 23, 135-194.

Bonnet Y. Analysis and prospects of the French bancassurance market [Electronic resource] / Y. Bonnet, P. Arnal // Association Actuarielle Internationale. Congres Interational des Actuaries. -9 p. - Mode of access : http://www.actuaries.org/EVENTS/

Congresses/Cancun/ica2002_subject/bancassurance/bancass_67_arnal.pdf. - Title from the screen.

Boot, A. (1999). European Lessons on Consolidation in Banking, Journal of Banking and Finance, 23, 609-613.

Boyd J. (1993). Bank holding company mergers with nonbank financial firms: Effects on the risk of failure. Journal of Banking \& Finance. 17(1), 43- 63.

Cetorelli, N. and Goldberg, L. (2011). Global Banks and International Shock Transmission: Evidence from the Crisis. IMF Economic Review, 59, 41-76.

Chen, H., Cummins, J.D., Viswanathan, K. S. and. Weiss, M. A. (2014). Systemic Risk and the Inter-Connectedness between Banks and Insurers: An Econometric Analysis. Journal of Risk and Insurance, forthcoming.

Cummins, J.D., Weiss, M.A. (2010). Systemic Risk and the U.S. Insurance Sector, working paper, Temple University, Philadelphia. Available at SSRN: http://ssrn.com/abstract=1725512. 
Daniel, J. (2000). The Integration of Financial Services in Europe. North American Actuarial Journal. 4, 53-63.

Freixas, X. (2003). Crisis Management in Europe. Financial Supervision in Europe, Edward Elgar, Cheltenham, 102-119.

Garcia-Herrero, A., Woolridge, P. (2007). Global and regional financial integration: progress in emerging markets. BIS Quarterly Review. September, 57-70.

Ghimire, R. (2013). Bancassurance: A Tool of Integrating Insurance and Banking Industries. Mirmire Monthly, 322, $1-7$.

Guiso, L., Jappelli, T., Padula, M., Pagano, M. (2004). Financial Market Integration and Economic Growth in the EU. Economic Policy, 19, 523-577.

Hastie, T., Tibshirani, R., Friedman, J. (2008). The Elements of Statistical Learning, second edition. Springer, New York, 2008, $737 \mathrm{p}$.

Jeon B., Olivero, M., Wu, J. (2013). Multinational banking and the international transmission of financial shocks: Evidence from foreign bank subsidiaries. Journal of Banking and Finance, 37, 952-972.

Kist, E. (2001). Integrated Financial Services - a Framework for Success: Synergies in Insurance, Banking, and Asset Management. The Geneva Papers on Risk and Insurance, 6 (3), 311-322.

Kozmenko, S.M. and Bagmet, K.V. (2011). Development of Regional Markets of Bancassurance: Foreign Experience.Vestnik NBU, 6, 20-26.

Nurullah, M. The Separation of Banking from Insurance : Evidence from Europe [Electronic resource] / M. Nurullah, S. Staikouras // Multinational Finance Journal, Global Business Publications : Quarterly publication of the Multinational Finance Society, a nonprofit corporation. - 2008. -Vol. 12, no. 3/4. -P. 157-184. - Mode of access : http://mfs.rutgers.edu/MFJ/Articles-pdf/V12N34p1.pdf. -Title from the screen.

Okeahalam, C. (2008). Does Bancassurance Reduce the Price of Financial Service Products. Journal of Financial Services Research. 33, 147-162.

Paige, F.L., Donald, F.R., James, K.W. (2007). Bidder returns in bancassurance mergers: Is there evidence of synergy? Journal of Banking \& Finance.. 31, 3646-3662.

Schoenmaker, D. (2010). The ECB, financial supervision, and financial stability management, in: de Haan, J., Berger, H. (eds), The European Central Bank at Ten, Springer, Heidelberg, 171-193.

Schoenmaker, D. (2011). The Financial Trilemma, Economics Letters 111, 57-59.

Schoenmaker, D. (2013). An Integrated Financial Framework for the Banking Union: Don't Forget MacroPrudential Supervision, European Economy - Economic Papers, forthcoming, DG ECFIN, Brussels.

Schoenmaker, D. (2013). Post-Crisis Reversal in Banking and Insurance Integration: An Empirical Survey. Economic Papers, 42 p.

Staikouras, S. (2006). Business opportunities and market realities in financial conglomerates. The Geneva Papers. $31,124-148$.

Staikouras, S. K. (2009). Between banks and insurance firms. Journal of International Financial Markets, Institutions \& Money. 19, 675-691.

Staikouras, S. K. An event study analysis of international ventures Standart\&Poors (2001), "European banking consolidation: Time -Out?", Commentary by Yves Burger, 25 October.

Sullivan, D. (1994). Measuring the Degree of Internationalization of a Firm, Journal of International Business Studies, 25, 325-342.

SWISS RE (2001). World Financial Centers: New Horizons in Insurance and Banking. Sigma 7.

Voutilainen, R. (2005). Comparing Alternative Structures of Financial Alliances . The Geneva Papers on Risk and Insurance. 30, 327-342. 


\section{NOTES}

